\title{
ПРАКТИКО-ОРИЕНТИРОВАННАЯ ПРОФЕССИОНАЛЬНАЯ ПОДГОТОВКА БУДУЩИХ ПЕДАГОГОВ В ХОДЕ МОДЕРНИЗАЦИИ ПЕДАГОГИЧЕСКОГО ОБРАЗОВАНИЯ
}

\section{PRACTICE-ORIENTED PROFESSIONAL TRAINING OF FUTURE TEACHERS IN THE COURSE OF MODERNIZATION OF TEACHER EDUCATION}

T. Dikova
E. Smirnova
T. Kovaleva
D. Zverev
D. Oreshin

Summary: The article highlights the issues of practice-oriented professional training of future teachers. The main directions of modernization of professional pedagogical education in higher education are revealed. It is shown that the priority directions of the development of Russian higher pedagogical education are the humanization of its content and pedagogical technologies, increasing accessibility and openness on the basis of system-activity and competence-based approaches. The modern requirements to professional detail of the teacher are revealed. It is shown that in the system of higher pedagogical education, the content of educational programs is updated from the point of view of their compliance with the needs of the labor market and the needs of employers. The practice-oriented approach is based on the organization of students ' training by modeling professionally-oriented pedagogical situations in the conditions of quasi-professional activity of future teachers. The article describes professionally-oriented technologies, forms and methods of teaching in the practice-oriented education of future teachers. It is shown that it is important to use active subject-activity forms and methods of teaching students. The role of pedagogical practice of students on the basis of general education institutions is revealed. It is shown that the practice-oriented nature of the training of future teachers implies close interaction between universities and educational institutions of general education. The article reveals the specifics of the network interaction of educational subjects in the practice-oriented training of future teachers.

Keywords: pedagogical education, modernization of education, practiceoriented training, quasi-professional activity of students, network interaction of the university and the school.
Дикова Татьяна Владимировна

Дочент, ГОУВО МО «Государственный социально-гуманитарный университет»

d.t.v@rambler.ru

Смирнова Елена Алексеевна

к.п.н., доцент, ГОУ ВО МО «Государственный социально-гуманитарный университет» tehfa.1974@yandex.ru

Ковалева Татьяна Анатольевна к.ф.н., доцент, ГОУ ВО МО «Государственный социально-гуманитарный университет» z-tatiana@yandex.ru

Зверев Дмитрий Сергеевич к.б.н., ГОУ ВО МО «Государственный социально-гуманитарный университет»

dima141080@yandex.ru

Орешин Дмитрий Николаевич к.п.Н., ГОУВО МО «Государственный сочиально-гуманитарный университет» dnikoreshin@hotmail.com

Аннотация: В статье освещаются вопросы практико-ориентированной профессиональной подготовки будущих педагогов. Раскрыты основные направления модернизации профессионального педагогического образования в высшей школе. Показано, что приоритетными направлениями развития отечественного высшего педагогического образования является гуманизация его содержания и педагогических технологий, повышение доступности и открытости на основе системно-деятельностного и компетентностного подходов. Раскрыты современные требования к профессиональной детальности педагога. Показано, что в системе высшего педагогического образования обновление содержания образовательных программ осуществляется с позиции их соответствия потребностям рынка труда и запросам работодателей. Практико-ориентированный подход основан на организации обучения студентов посредством моделирования профессионально-ориентированных педагогических ситуаций в условиях квазипрофессиональной деятельности будущих педагогов. Описаны профессионально-ориентированные технологии, формы и методы обучения в практико-ориентированном образовании будущих педагогов. Показано, что важным является применение активных субъектно-деятельностных форм и методов обучения студентов. Раскрыта роль педагогической практики студентов на базе общеобразовательных учреждений. Показано, что практико-ориентированный характер обучения будущих педагогов предполагает тесное взаимодействие вузов и образовательных учреждений общего образования. Раскрыта специфика сетевого взаимодействия субъектов образования в практико-ориентированном обучении будущих педагогов.

Ключевые слова: педагогическое образование, модернизация образования, практико-ориентированное обучение, квазипрофессиональная деятельность студентов, сетевое взаимодействие вуза и школы. 
$\Pi$ роцессы модернизации системы высшего профессионального образования на современном этапе его развития, в том числе и в сфере профессиональной подготовки будущих педагогов, связаны с глобализацией и информатизацией общественных отношений. Важными направлениями развития отечественного высшего образования является гуманизация его содержания, используемых в образовательном процессе педагогических технологий, повышение его доступности и открытости на основе реализации системно-деятельностного подхода и компетентностно-ориентированной парадигмы образования, задающей ее целевые и содержательно-технологические ориентиры.

В этих условиях будущему педагогу необходим и новый уровень профессионального развития, который связан с новым способом педагогического мышления и деятельности, новым отношением к себе как профессионалу и ученикам как к свободным и ответственным людям. Современные педагогические подходы и технологии обучения, которые осваивают студенты в процессе получения высшего педагогического образования, требуют реализации внутренних и внешних профессиональноличностных ресурсов будущего педагога. Одной из целей высшего профессионального образования является подготовка конкурентоспособных выпускников, будущих педагогов, которые могут успешно адаптироваться к инновационным процессам в образовании, способных к профессиональному росту и профессионально-личностному саморазвитию в педагогической деятельности. Современному педагогу выдвигаются иные требования к профессиональной деятельности, связанные с утверждением системно-деятельностного подхода, что отражено в Федеральных государственных образовательных стандартах основного общего образования [7]. К таким требованиям относятся, по мнению О.Л. Жук, «изменение педагогических целей с передачи знаний на самореализацию обучающихся; вариативность образования и его учебно-методического сопровождения; изменение характера взаимодействия преподавателя и обучающихся; расширение образовательного пространства учебного заведения, сети социальных партнеров, выступающих субъектами образования; развитие исследовательского пространства образовательного учреждения и исследовательской деятельности его субъектов $[3$, c. 65]; «изменение оценки достижений обучающихся, востребованность диагностических и прогностических умений педагога» [6, с. 17]. С другой стороны, современные тенденции в системе высшего педагогического образования заключаются в обновлении содержания образовательных программ высшего образования с точки зрения их привлекательности и соответствия потребностям рынка труда и запросам работодателей.
Актуальность приобретают вопросы практико-ориентированной профессиональной подготовки будущих педагогов в ходе модернизации педагогического образования на основе взаимодействия вузов с образовательными учреждениями системы дошкольного и общего образования.

Практико-ориентированный подход в профессиональном педагогическом образовании в самом общем виде рассматривается как профессиональная подготовка будущих педагогов на основе взаимопроникновения учебной и профессиональной деятельности студентов как условия формирования учебно-профессиональных компетенций. Практико-ориентированный подход предполагает организацию образовательного процесса посредством моделирования в учебном процессе профессионально-ориентированных педагогических ситуаций в условиях квази-профессиональной деятельности. Необходимым является определение понятия «практико-ориентированная профессиональная подготовка будущих педагогов», которое трактуется как «система поэтапного вовлечения студентов в процесс познания фундаментальных предметных знаний через освоение технологий их качественного и количественного отбора, систематизации и оценивания их достоверности, через использование комплекса профессионально-ориентированных технологий, форм и методов обучения» $[4, \mathrm{c}$. 8]. В этой связи интерес представляют формы, методы и приемы педагогический деятельности, которые обеспечивают практико-ориентированные характер вузовского обучения будущих педагогов.

Во-первых, практико-ориентированное обучение в вузе предполагает создание квазипрофессиональной среды, которая, согласно А.А. Вербицкому, определяется как обучение, в котором динамически моделируется предметное и социальное содержание профессионального педагогического труда, что способствует трансформации учебной деятельности студентов в профессиональную деятельность педагога [1]. Организация квазипрофессиональной среды осуществляется посредством активных методов обучения - проведения диспутов, ролевых и деловых игр, проблемных методов обучения, которые реализуются во время проведения практических занятий по учебным дисциплинам, предусмотренным учебными планами соответствующих направлений подготовки. Квазипрофессиональная деятельность будущих педагогов рассматривается как связующее звено между учебной и профессиональной деятельностью, которая реализуется на непрерывной основе посредством приобретения опыта разрешения моделируемых в учебном процессе проблем будущей педагогической деятельности на основе взаимодей- 
ствия студентов, преподавателей вузов, а также педагогов-практиков [4]. В практико-ориентированном обучении важным является применение активных субъектно-деятельностных технологий обучения студентов, которые способствуют активизации студентов как субъектов учебно-профессиональной деятельности. Использование данных педагогических технологий в образовательном процессе при организации обучения от учебной деятельности к квазипрофессиональной обеспечивает соприкосновение с ценностями и целями профессии и формирование профессиональных компетенций будущего педагога.

Реализация практико-ориентированного обучения в первую очередь осуществляется во время прохождения производственной практики студентов на базе общеобразовательных учреждений. Педагогическая практика, являясь важной частью профессионально-педагогической подготовки будущих педагогов, выступает в качестве квазипрофессиональной деятельности, которая обеспечивает перестройку учебной мотивации на учебно-профессиональную мотивацию, формируя, таким образом, профессионально-важные качества будущего педагога и его профессиональные педагогические компетенции. В Вастоящее время в вузах реализуются различные модели практической подготовки будущих педагогов, которая направлена на формирование профессиональных педагогических умений и навыков, на развитие интереса к профессии учителя, что имеет важное значение для профессионально-личностного развития будущего педагога. Во время прохождения производственной практики на старших курсах обучения студенты практически полностью выполняют функциональные обязанности учителя на основе уже сформированных теоретических знаний. Вариативность форм и содержания производственной практики будущих педагогов обеспечивает перестройку учебных мотивов на учебно-профессиональные, формирование профессионально-важных качеств и навыков, создавая образ профессионала и траекторию профессионального пути [5].

Практико-ориентированный характер обучения будущих педагогов предполагает тесное взаимодействие вузов и образовательных учреждений общего образования. На уровне кадрового обеспечения практико-ориентированного обучения будущих педагогов следует отметить следующее. Профессорско-преподавательский состав вузов как специалисты высшей школы обладают «методологией работы с предметным содержанием, ориентируются в современной научной литературе, владеют современными представлениями и навыками исследовательской деятельности» [2, с. 118]. Педагоги общеобразовательных учреждений, в свою очередь, являются специалистами «в вопросе организации образовательной деятельности с учащимися, владеют современными образовательными технологиями и навыками практической деятельности по использованию знаний в образовательном процессе» [2, с. 118]. Объединение кадровых ресурсов образовательных организаций и высшей школы в профессиональной подготовке будущих педагогов является условием, повышающим качество обучения студентов. Результативность практико-ориентированной профессиональной подготовки будущих педагогов, как отмечает А.А. Костюнина, возможна при реализации педагогических технологий, которые опираются на «консолидацию потребностей и возможностей всех субъектов образовательного процесса при совместной ответственности студентов, преподавателей, администрации школ и ресурсное обеспечение информационно-технологических и образовательных инноваций в теоретической, практической, научно-исследовательской подготовке будущих педагогов» [4, с. 9].

В условиях модернизации высшего образования получила развитие идея сетевого взаимодействия субъектов образования, которое также способствует реализации практико-ориентированного обучения будущих педагогов. Привлечение руководителей образовательных учреждений, выступающих в качестве работодателей, а также педагогических коллективов к организации различных направлений взаимодействия вузов и образовательных учреждений общего образования, позволяет повысить качество обучения студентов, способствует формированию учебно-профессиональной мотивации и практических педагогических навыков и умений. Эффективность сетевого взаимодействия определяется тем, что сетевое образовательное пространство существует параллельно структурированной и институциональной образовательной системе, в рамках которого «взаимодействие осуществляется не на базе конкретного образовательного учреждения - школы или вуза, а в рамках сетевых образовательных программ, которые могут реализовываться даже в виртуальной среде» [2е, с. 59]. С введением сетевого взаимодействия между педагогическими вузами и образовательными организациями общего образования могут создаваться кафедры и иные структурные подразделения, обеспечивающие практическую подготовку студентов на базе образовательных организаций ступеней дошкольного и общего образования. Организация кафедр позволяет использовать в образовательной деятельности вузов результаты педагогических инноваций, реализуемых в образовательных учреждениях, расширить практико-ориентированный характер обучения студентов. Создание базовых кафедр позволяет вузам совершенствовать образовательный процесс посредством включения студентов, будущих педагогов, в педагогическую деятельность по реализации 
современных педагогических инноваций [2].

Таким образом, практико-ориентированный характер обучения в условиях модернизации педагогического образования предполагает, с одной стороны создание квазипрофессиональной среды в вузе на основе внедрения субъектно-деятельностных активных технологий обучения, с другой - разнообразие форм взаи- модействия вузов с общеобразовательными учреждениями, являющимися потенциальными работодателями будущих педагогов. Организация практико-ориентированного обучения способствует усилению профессиональной мотивации студентов, формированию их профессиональных умений и навыков, приобретения опыта профессиональной деятельности, что обеспечивает повышение качества профессионального педагогического образования.

ЛИТЕРАТУРА

1. Вербицкий А.А. Теория и технологии контекстного образования: учебное пособие. - Москва: МПГУ, 2017. - 266 с.

2. Взаимодействие вузов и школ для становления Открытого образовательного пространства: потенциал, проблемы, задачи управления/ Под ред. Г.Н. Прозументовой. - Томск: Томский государственный университет, 2013. - 194 с.

3. Жук 0.Л. Педагогическая подготовка студентов: компетентностный подход. - Минск: РИВШ, 2009. - 336 с.

4. Костюнина А.А. Практико-ориентированная профессиональная подготовка будущих педагогов в ходе модернизации педагогического образования: автореферат дис. ... канд. пед. наук: 13.00.08. - Барнаул, 2016. - 23 с.

5. Маняйкина Н.В. «Задачный подход» В педагогической практике будущих учителей иностранного языка как условие формирования их профессиональной направленности: автореферат дис. ... кандидата педагогических наук: 13.00.02. - Екатеринбург, 2009. - 22 с.

6. Чекалева Н.В. Изменения в деятельности преподавателя педагогического вуза в контексте инновационного образования // Письма в Эмиссию: электронный научный журнал. - 2011. - № 9. - С. 16-43.

7. Федеральный государственный образовательный стандарт основного общего образования / Минобрнауки РФ. - М.: Просвещение, 2011. - 48 с.

( Дикова Татьяна Владимировна (d.t.v@rambler.ru), смирнова Елена Алексеевна (tehfa.1974@yandex.ru),

Ковалева Татьяна Анатольевна (z-tatiana@yandex.ru), Зверев Дмитрий Сергеевич (dima141080@yandex.ru), Орешин Дмитрий Николаевич (dnikoreshin@hotmail.com).

Журнал «Современная наука: актуальные проблемы теории и практики»

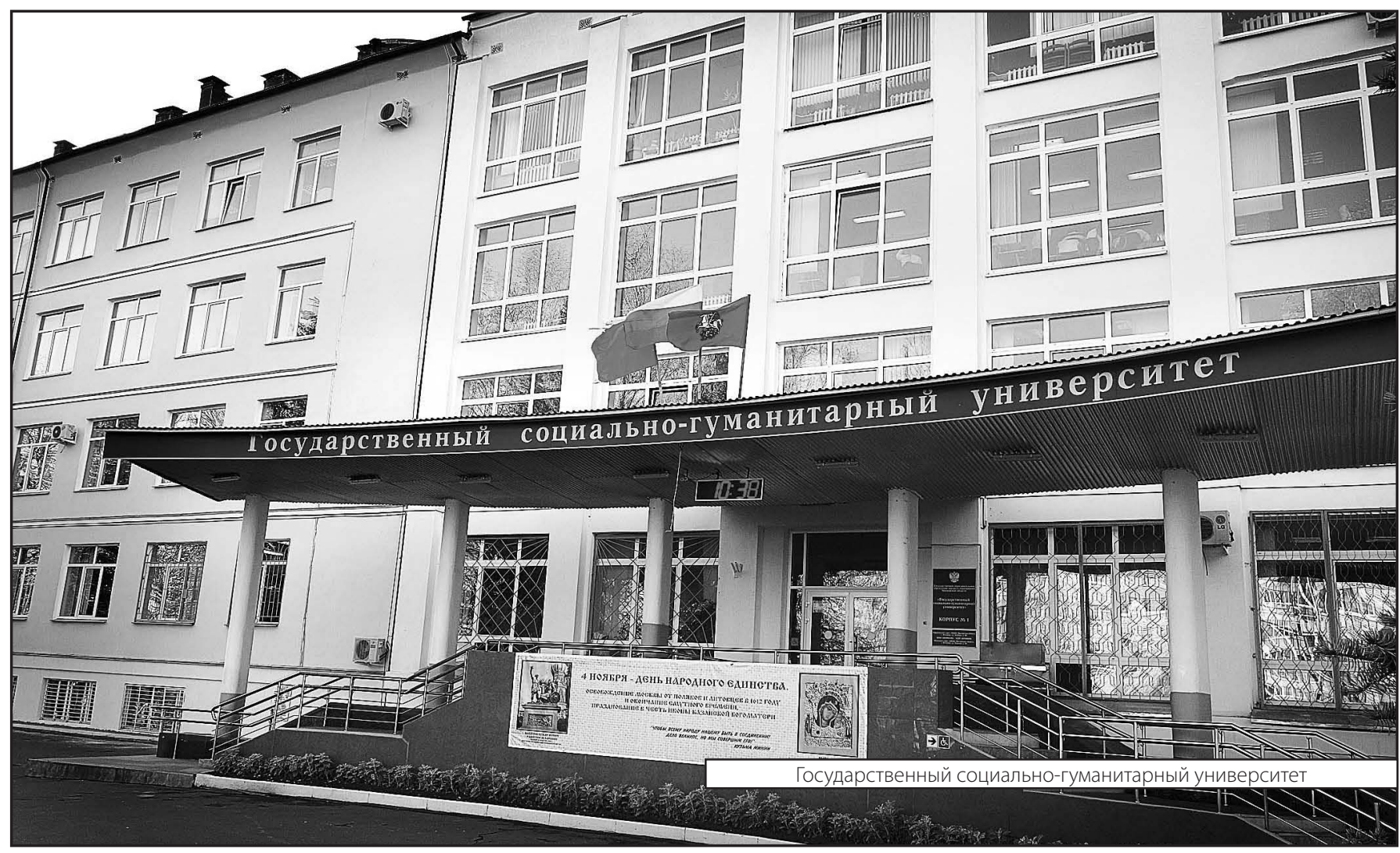

